\title{
The Development of Islamic-Based Pancasila and Civic Education Curriculum at Junior High School: Research at Junior High Schools in Cluster 5 Bandung Regency
}

\author{
Teguh Prayitno, Agus Salim Mansyur, Adang Hambali, Yuyun Nurul'aen \\ Universitas Islam Negeri (UIN) Sunan Gunung Djati, Bandung, West Java, Indonesia \\ Email: tprayitno65@gmail.com, agussalimmansyur@uinsgd.ac.id, adanghambali@uinsgd.ac.id, \\ yuyunurulaen@uinsgd.ac.id
}

\section{ARTICLE INFO \\ Received: 08-09-2022 \\ Revision: 13-09-2022 \\ Received : 20-01-2022 \\ Keywords: \\ Islamic-based; \\ Pancasila; civic \\ education; Junior High \\ School}

\section{ABSTRACT}

This research departs from an idea of how to develop an Islamicbased Civics curriculum that can improve morality (character building or character). The research conductedat SMPN 1 Cileunyi, SMPN 1 Cilengkrang, and SMPN 2 Cimenyan. An Islamic-based Civics Curriculum development design can inspire independent learning in a student-centric learning process and an Islamic teacher. The core values Islamic values into goals, programs, implementation, and evaluation. The primary purpose of this study was to determine the implications of Islamic-based Civics Curriculum Development in Junior High Schools that internalize Islamic values. This research used qualitative research and development, a process or steps to develop a new product or improve an existing product, which can be accounted for. Data collection techniques were obtained using library research, observation, interviews, questionnaires, and documentation studies. The result shows the implementation of Islamic-based Civics curriculum is based on the Thirteenth Curriculum, yet, or although there are still embryos of Islamic religious, moral values, teachers provide spiritual support in the learning process; The teaching resources are indeed less mastered on religious material so that teachers are needed who have two competencies, namely the competence of Civics and religious material.

\section{Introduction}

Pancasila Education and Civics (PPKn) is dominated by the process of value education and knowledge dissemination. This can be seen from the learning materials that are developed based on the points of each of the Pancasila precepts. The learning objectives are also directed to instil attitudes and behaviours based on Pancasila values and develop knowledge and abilities to understand, appreciate and believe in
Pancasila values as guidelines for daily behavior (Wirataputra, 2001).

Based on the enactment of the National Education System Law No. 20 of 2003, a curriculum known as the Competency-Based Curriculum was implemented in 2004, where Civics changed its name to Citizenship. In 2006 the name changed back to Civics (PPKn), where substantially there were no significant changes, only the authority for curriculum

How To Cite: $\quad$ Teguh Prayitno, Agus Salim Mansyur, Adang Hambali, Yuyun Nurul'aen. (2022). The Development of Islamic-Based Pancasila and Civic Education Curriculum at Junior High School: Research at Junior High Schools in Cluster 5 Bandung Regency. Journal of Social Science, 3(1). 
development was delegated to each education unit, so the 2006 curriculum is known as the Education Unit Level Curriculum (KTSP).

Various changes experienced in the implementation of PPKn as described above indicate that there has been a lack of consistency in the framework of thinking which at the same time reflects the occurrence of a conceptual crisis that has an impact on the occurrence of a curricular operational crisis regarding names, content, methods, strategies, and goals.

From the use of the term, it was evident that it is not consistent in organizing civic education, which results in an operational crisis, where there is a change in the context and format of the education. Civics programs are still running independently. The nation's problems, especially in efforts to develop exemplary citizens, have not been optimal in the scope of Civics as a curricular program.

In particular, in terms of the objectives of Civics, the implementation of Civics in Indonesia is still not as expected. Many cases reflect the failure to form an educated and intelligent citizen. We find many cases of law and moral violators committed by the younger generation and our students, such as anarchy brawls, drug abuse, crime, immoral cases and others. Various internal and external factors caused the emergence of these cases.

Internal factors arise from the condition of education in Indonesia, which has not been able to form excellent and intelligent citizens. The limited competence of teachers influences this educational condition. professional and pedagogical competence External factors are dominated by the swift currents of globalization, which impact the fast flow of information entering Indonesia uncontrollably. The 'democratic faucet' that was opened too wide after the reform has brought this nation to the euphoria of freedom that tends to be unlimited.
Teachers and students who are within the Civics academic community, are facing several problems which become weak points as mentioned by (Wahab, 2007), there are:

1) Incomplete foundations. Ideally, the foundation of Civics as a curricular program includes philosophical, ideological, constitutional, socio-cultural, and academic foundations.

2) Curriculum organization is not adequate. The curriculum organization should have a system for each level of education, elementary, junior high, high school.

3) Weak book quality. Our books are relatively weak in content, writing method, and appearance.

4) Weak methodology. The weakest part of the social sciences is the method aspect compared to the exact sciences.

5) Teacher competition. The teacher does not have a teaching background in Civics.

Responding to point 2, the Curriculum Organization is inadequate. The era of globalization and information is so fast globalizing. So the importance of the role and function of the curriculum should have been very well recognized in the national education system. Why is that? Because the curriculum is a crucial tool in realizing educational programs, so the picture of the spirit of the education system can be seen clearly in the curriculum, especially PPKn.

In line with the demands of global advances in science and technology by the socio-political situation, the Civics Curriculum demands innovation. These innovations adapt to the demands of the times and the demands of the educational goals themselves. So curriculum development on this fundamental dimension requires curriculum development to answer it.

According to Oemar Hamalik, Curriculum development is a very essential part of the learning process of subjects (including PPKn). There are 4 essential parts in the curriculum: objectives, content/materials, learning strategies, and evaluation (Oemar, 2013). All these 
components are interrelated and interact to achieve the behaviour aspired by the subject's objectives.

Clear objectives will also provide clear instructions in selecting the content/materials that must be mastered, the strategies to be used and the appropriate forms and evaluation tools to measure curriculum achievement. The hierarchy of curriculum goals formulation starts from general educational goals, institutional goals, curricular goals, and instructional goals.

Furthermore, in the context of designing/developing a curriculum, according to Ahmad, interpretation means considering values. These values must be the highest values that are true, higher in position than the curriculum itself. These values determine the formulation of our goals, while the curriculum is only a tool or a way to achieve that goal. For Muslims, the highest values they believe in are the values contained in the Qur'an and Hadith (Tafsir et al., 2004). Therefore both are used as the basis for the educational theory they want. The current concept is character education for Muslims who have good morals or in terms of Islamicbased education.

Juhana (Head of the Bandung Regency Education Office) said (Juhana, 2016) : that the Bandung Regency Education Office's Islamic-based concept began in the Islamic Religion subject in the 1990s to guide other general subjects. This concept is known as the integralists curriculum. The core values of Islam are integrated into the curriculum (subject-centred design) and learning (Learner-centered design). In line with the development of the era of this integrality curriculum, the term Islamic fundamental values have changed to "ethics" which is the barometer of value education. Moreover, in this millennium 4.0 era, the term "character education" leads to the nawacita in Jokowi Widodo's government. Character education explores five central character values originating from Pancasila (five character values that are priorities for the development of the PPK movement; namely, religious, nationalism, integrality, independence, and mutual cooperation). Our hope can be realized into character education and Islamic moral based.

Based on researchers' observations at Cluster 05 State Junior High School that (Prayitno, 2017): in Cluster 05 Kab. Bandung The existence of a decent potential to be in harmony, harmonious and balanced religious values (Islam-based) can be integrated, especially in Civics subjects, because PPKn I00\% qualified Moslem teachers can read and write the Qur'an (BTQ) and al Hadith. Moreover, for students $\pm 98 \%$ are Muslims through habituation education for the implementation of BTQ, congregational midday prayers, dhuha prayers, religious lectures and commemoration of religious holidays, and district religious competitions. This activity is one of the main parts of strengthening the nation's character revolution or mental revolution (Nawacita agenda no 8, PPK Movement 2010 and Permendikbud No 23 of 2015).

The results of the interview with Zaenal Arifin (Supervisor of PPKn) (Arifin, 2017) said that the reason students paid less attention to Civics subjects was not due to the unattractive teaching style of the teacher; the media and methods used were monotonous and in explaining the teacher's material was not by the curriculum. existing ones, but does not link the subject matter (KDP syllabus) with actual problems with the religious values that become his beliefs. Behave by the objectives of PPKn, but it is only a culture, but it has not become a spirit of belief. The meaning seems moral but empty of religious spirit values (theological crisis).

The general phenomenon of problems found in PPKn teachers in learning activities is only as a good syllabus funnel (revised 2013 PPKn Curriculum); there is no courage for teachers to develop their curriculum to integrate or correlate Islamic religious values into the draft syllabus (PPKn Curriculum). The development of the Civics Education 
curriculum is based on Islam, in the study of Subject-centered design, namely the design centred on Islamic-based Civics subjects, especially the essential competencies (KD) of spiritual attitudes to describe $\mathrm{KI}-1$; and Learner-centered design. Namely, a design centred on Islamic-based Civics learning KD spiritual attitudes to describe KI-1.

This problem is a crucial problem that must be resolved immediately to complement the existing curriculum to be developed by the local environmental situation with a pattern of developing a Civics curriculum with proven validity and reliability. new to developing the curriculum.

An alternative to this concept is developing an Islamic-based Civics Curriculum. Based means based on the values of Islamic teachings. What is the reason that Civics Curriculum Development is based on the values of Islamic teachings? Muhammad Alim says:

Religious values are noble values that are transferred and adopted into oneself. Therefore, how much and how far religious values can influence and shape a person's attitudes and behaviour depends on how deeply religious values are internalized within him. The deeper religious values are internalized in a person, his religious personality and attitudes will emerge and be formed. If a religious attitude has emerged and is formed, then religious values will become the centre of value in responding every situation of life (Alim, 2006).

In connection with the above context, the author responds to Research and Development (R \& D) applying Islamic-based Civics Curriculum Development at State Junior High Schools Cluster 5, Bandung Regency, which is allegedly the most effective, efficient and productive curriculum development to achieve its goals.

Rizal (2021) investigated curriculum development and concluded that curriculum in Indonesia cannot be isolated from the essential ideas created from educational philosophy. He also examines the evolution of
Islamic education in Indonesia through literature and its implications for Indonesian curriculum development. This research differs from this one in that it examines curriculum development in a number of junior high schools.

The author sees this phenomenon and then conducts a thought study on dissertation research with the title "Development of Islamic Based Civics Curriculum in Junior High Schools" (Research at SMP Negeri 1 Cileunyi, SMP Negeri 2 Cimenyan and SMP Negeri 1 Cilengkrang Cluster 05 Kab. Bandung).

\section{Method}

This research used Research and Development ( $R \& R \& D)$. This research and development method has been widely used in the fields of Natural Sciences and Engineering. Almost all technological products, such as electronic equipment for motor vehicles, aeroplanes, ships, weapons, drugs, medical equipment, high-rise buildings and modern household appliances, are produced and developed through research and development (Sugiyono, 2013).

The research and development method or Research and Development (R \& D) is the process or steps for developing a new product or perfecting an existing product, which can be accounted for. Meanwhile, according to Sugiyono Research R\&D, research methods are used to produce specific products and test the effectiveness (Sugiyono, 2013).

In the field of education, the products produced through $R$ \& $D$ research is expected to increase education productivity, namely a large number of graduates, quality, and relevant to the needs. Educational products such as specific curriculum for certain educational needs, teaching methods, educational media, textbooks, modules, competency of education personnel, evaluation system, competency test model, classroom arrangement for certain learning models, production unit models, management models, employee development system, 
The Development of Islamic-Based Pancasila and Civic Education Curriculum at Junior High School: Research at Junior High Schools in Cluster 5 Bandung Regency

payroll system, and others (Sugiyono, 2013). The research takes place in three Junior High Schools in Bandung

Initially, $R \& D$ is closely related to experimental research methods; experimental research methods are the most precise and accurate methods to fulfil the functions of science, namely explanation, predicting, and controlling. The experimental method has a strict, systematic, structured, and measurable structure to test the causal relationship or influence with strict and transparent controls and precise and accurate statistical calculations (Nusa, 2011).

It can be used as an effort to change attitudes or encourage new attitudes using experimentation. This experiment develops the Civics Education Curriculum based on the Junior High School Level for teachers and students.
Educational Research and development (R\&D) in this study is the Civics Education Curriculum at the Junior High School Level, which is allegedly still necessary to integrate the old product (which already has formal legitimacy) with the prototype of new product development is added value. The added value, in this case, is the Islamic values that are the basis and are believed to be in the lives of teachers and students in implementing the Islamic-based Civics Curriculum.

This Educational Research and development (R \& $D$ ) is the Development of Islamic-Based Civics Education in Junior High Schools" (Study at SMP Negeri Gugus 05 Kab. Bandung).

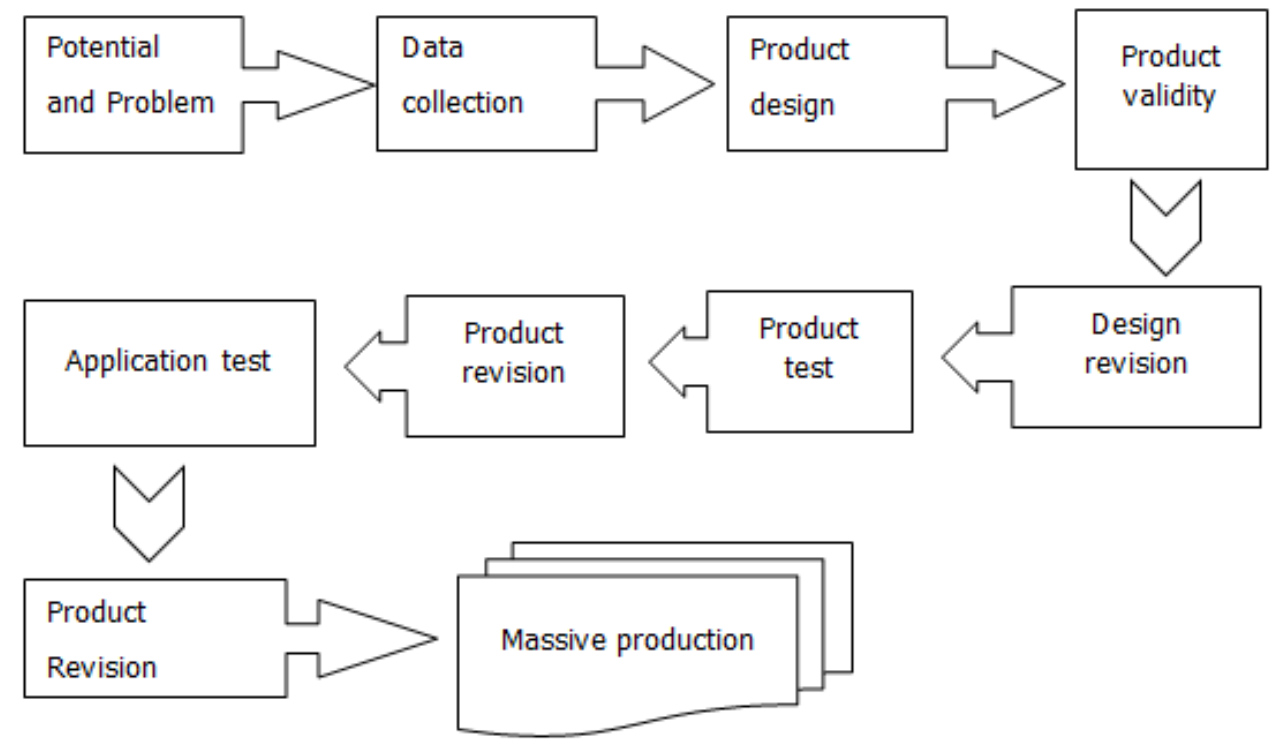

Figure 1

Research Flow

Research and Development (R\&D) method chart

\section{Results And Discussion}

\section{Objective conditions of the Civics Curriculum at SMP Negeri Cluster 05, Bandung Regency}

To identify the objective conditions of the Civics curriculum at SMP Negeri Cileunyi
1, SMP Negeri 2 Cimenyan and SMP Negeri 1 Cilengkrang the results are:

\section{a) PPKn Curriculum Design}

The Civics curriculum relies on the national curriculum made by the government based on the nation's characteristics. The substance of the curriculum above shows that the substance of the PPKn study does not 
contain Islamic values. However, the results of interviews with PPKn teachers show that explicitly there are no Islamic values in the Civics curriculum, but teachers always give Islamic values in learning (hidden curriculum).

\section{b) PPKn Curriculum Implementation}

The substance of the study of the Civics Education curriculum, which is implemented in classroom learning, is carried out with the following steps:

1) Introductory Activities

Preliminary activities carried out by PPKn teachers in the form of motivating students in various ways adapted to students' conditions. After that, the teacher will do an apperception to find out students' knowledge about the material to be taught and to condition students so that students focus their attention on the learning that will begin.

2) Core activities

In the core activity of learning Civics material based on Islamic values to improve students' morals, the teacher tries to use various methods and approaches to achieve the PPKN learning objectives that have been planned according to the learning objectives. The methods used include lectures, question and answer, group discussions, class discussions, simulations, and so on with learning steps in the form of delivering learning materials first by the syllabus then combined with practice questions and worship practices in groups and individually.

3) Closing

In this closing activity, PPKn teachers make conclusions together with students from the material that has been presented. Moreover, learning is also carried out with the steps relying on the opinion of Abdul Majid, who says that procedurally, the steps for implementing learning are described in three categories, namely opening, core activities and closing.

- Introduction (Opening)
The introduction can be called the initiating, initiating, invitation, apperception, or alpha zone stage, which is bait to focus on learning. Students can be given motivation that stimulates awe and enthusiasm for studying. This introduction can be in the form of questions about student experiences in everyday life. This is done to create continuity of knowledge between events known to students and the material to be discussed. Students are allowed to express their opinions on interesting stories based on the topics raised for the teacher. The introduction is also a means for the teacher to express the purpose of learning.

- Core Activities (Activities)

The teacher provides material related to the activities that students will carry out. This activity's benefit is that students have the knowledge and skills needed to develop themselves in the next lesson. The teacher can provide a worksheet as a direction for students to work on projects. The teacher can place students in groups to discuss the project to be made. The teacher can guide students in large (classical) groups to convey the discussion results. This activity serves to share knowledge by presenting the results of activities according to the worksheets or projects that have been done. The teacher can ask other group members to respond to the presentation and provide feedback to students.

- closing (closing)

The teacher strengthens learning activities through emphasis on key concepts. The teacher does this by guiding students to conclude all the learning materials being studied. In the closing stage, students can be given homework to apply their knowledge to their home and environment. In 
addition, the teacher helps students to reflect or evaluate their performance. Improvements or additions if there are errors and deficiencies (Majid, 2014, p. 129).

In Civics learning activities, it can be seen that students have a huge role in teaching and learning activities. This is inseparable from the role of the teacher who must be able to create conditions or strategies in active student learning. According to Slavin, knowledge of the subject matter is not a person's problem to teach effectively. Effective teachers know the subject matter and can convey their knowledge to students. The link between what teachers want students to learn and actual student learning is called instruction, or pedagogy. Effective teaching is not a simple matter of people who have more knowledge transferring that knowledge to others. On the other hand, effective teaching requires the use of multiple strategies.
A good teacher can motivate students, manage classrooms, assess prior knowledge, convey ideas effectively, consider student characteristics, assess learning outcomes and review information. What makes a teacher suitable is his ability to do all the tasks contained in effective teaching (Ahmadi, Amri, \& Elisah, 2011).

\section{Implementation of the developed Islamic-Based Civics Curriculum at Junior High School Cluster 05, Bandung Regency}

The development of a Civics curriculum based on Islamic values at SMP Negeri 1 Cileunyi, SMP Negeri 2 Cimenyan, and SMP Negeri 1 Cilengkrang, Bandung Regency which was developed in this study, is not much different from other curriculum designs which include objectives, materials, implementation and evaluation. The figures for the design of the Civics curriculum based on Islamic values are arranged Figure 2. 


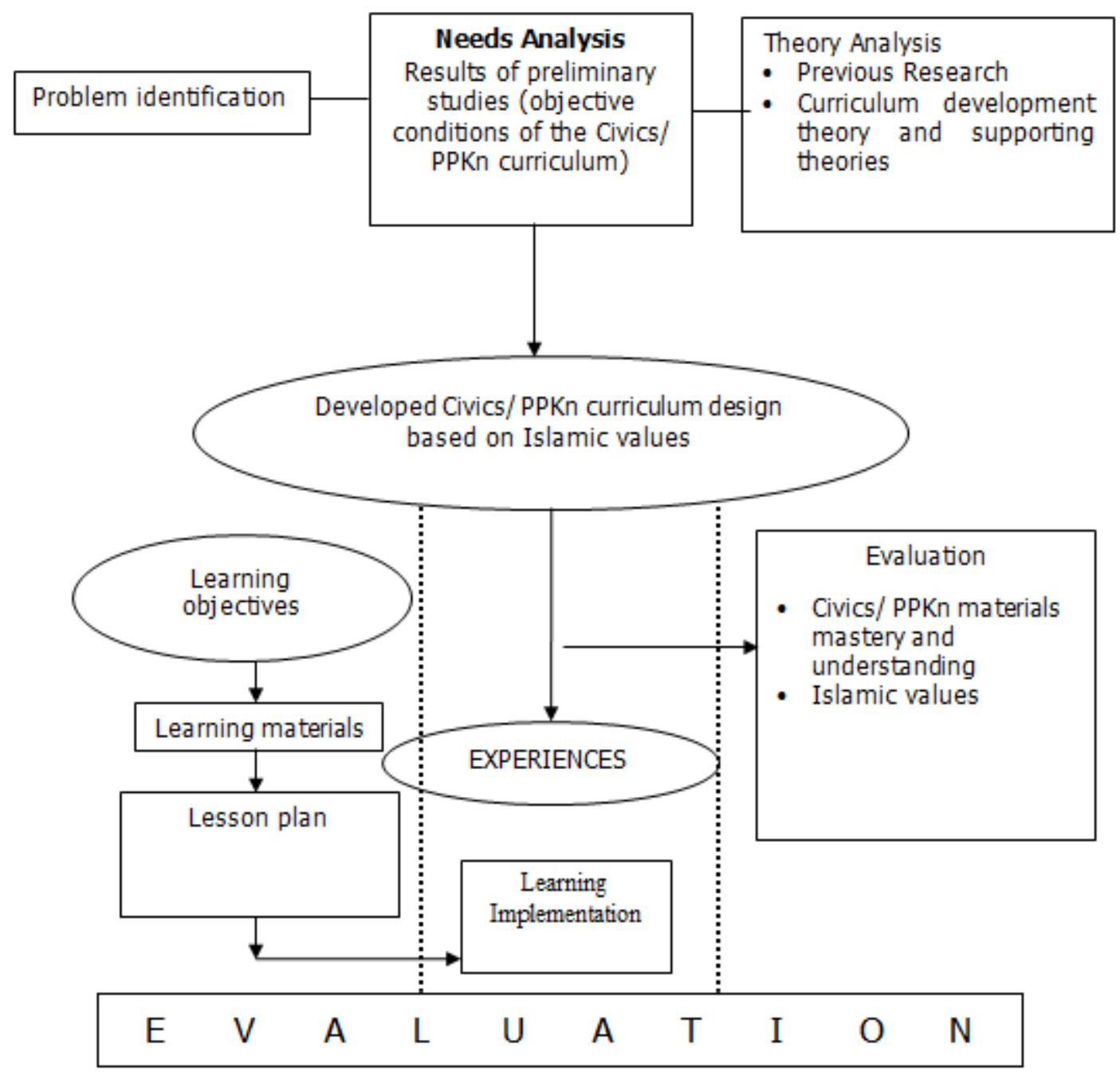

Figure 2

The development of Islamic-based Civic (PPKn) curriculum design

Civics material based on Islamic values and supporting theories. The Civics curriculum based on Islamic values was developed based on problem identification and needs analysis obtained from preliminary studies, theoretical analysis based on previous research, development theory and integrative curriculum. As for the planning and implementation of the curriculum, Civics materials based on Islamic values developed are as follows:

a) Planning that contains essential competencies, indicators of competency achievement, learning objectives; teaching materials, and lesson plans (RPP);
1) Learning objectives
(Basic

learning objectives are formulated in the editorial which is still general in nature and describes the achievement of student outcomes. Learning objectives are formulated based on KD and competency achievement indicators developed with Islamic values;

2) Theory; teaching materials are developed based on learning objectives (KD and indicators) that have been formulated and integrated with Islamic values;

3) Evaluation; to find out the increase in understanding of Islamic values. 
(Yusran, 2017) As for Islamic values, when viewed from the source, they are classified into two types, there are:

a) Divine values are values that come from the Qur'an and hadith. Religious values in the aspect of theology (rules of faith) will never change and do not tend to change or follow human desires. At the same time, the natural aspects can change according to the times and the environment.

b) Human Values Human values grow and develop based on human agreement. This human value will continue to develop in a more advanced and higher direction. This value comes from ra"yu, customs and natural reality.

A person's diversity is manifested in various aspects of his life. Religious activity occurs when a person performs ritual behaviour (worship) and when carrying out other activities driven by supernatural powers. It is related to activities that are visible and can be seen with the eyes and activities that are not visible and occur in one's heart (Ancok, Suroso, \& Ardani, 2000).

In things that are not visible, this is in the heart that is difficult for humans to see but only by the Creator because the barometer in the heart is the "intention" of one's charity, behaviour, or activity. In this case, the intention is the benchmark for practise; whether it is accepted or not depends on the intention and the amount of reward obtained or at least depends on the intention. A person can rise to the rank of shiddiqin and fall to the lowest level (afalan safiliin) because of his intention. According to the hadith of the Prophet S.A.W:

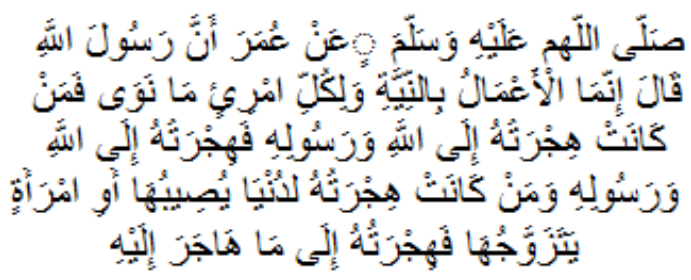

From Umar radhiyallahu 'anhu, that the Prophet sallallaahu 'alaihi wa sallam said,
"Charity depends on the intention, and a person only gets according to his intention. Whoever emigrated to Allah and His Messenger, then his emigration was to Allah and His Messenger, and whoever emigrated for the sake of the world or because of the woman he wanted to marry, then his emigration was according to where he emigrated." (Bukhari, 2014).

\section{Evaluation of the developed Islamic- Based Civics Curriculum at SMP Negeri Cluster 5, Bandung Regency}

Evaluation is essentially the determination of the results and meaning of a program based on the information obtained using the criteria used. Evaluation is basically used to see the weaknesses, shortcomings, and obstacles of a program that evaluates at the level of planning and implementation of a program and evaluates the program's evaluation system holistically.

About the curriculum, evaluation is limitedly defined as a tool to check the level of achievement of educational goals to be realized through the curriculum in question. Broadly, curriculum evaluation is a tool to examine curriculum performance as a whole (holistic) in terms of various criteria to see the program's effectiveness.

Curriculum evaluation is the process of applying scientific procedures to collect valid and reliable data to make decisions about the current or existing curriculum. In simple terms, curriculum evaluation can be equated with research because curriculum evaluation uses systematic research, applying scientific procedures and research methods. It is essential to evaluate the curriculum to adapt it to the development of science, technological advances and market needs. There are many problems in implementing curriculum evaluation such as the theoretical basis used in curriculum evaluation is weak, educational interventions that are carried out do not allow blinding, difficulties in randomizing, difficulties in standardizing the interventions carried out, research ethics 
problems, the absence of pure outcomes, difficulties in finding tools measure and use different curriculum perspectives as a comparison. Therefore, by understanding the meaning of curriculum evaluation and its similarities and differences with research, it is hoped that the curriculum evaluation that will be made can be valid, reliable, and valuable in making decisions about the curriculum.

Curriculum evaluation can cover the entire curriculum or individual curriculum components such as objectives, content, or learning methods in the curriculum. In simple terms, curriculum evaluation can be equated with research because curriculum evaluation uses systematic research, applies scientific procedures and research methods. The difference between evaluation and research lies in its purpose. The evaluation aims to collect, analyze, and present data to decide whether to be revised or replaced. In comparison, research has a broader purpose than evaluation: collecting, analyzing, and presenting data to test or create new theories.

The primary purpose of evaluating the development of an Islamic-based Civics curriculum is to determine the effectiveness in the learning process. The learning process is a description of the achievement of student learning competencies. Evaluation of Islamicbased Civics learning material is used to measure student learning achievement. The evaluation can be in the form of an oral test, written test, practice and simulation.

Evaluation is often seen as the end of the whole process. Students are evaluated at the end of the program. Teachers are evaluated at the end of the probationary period. The curriculum is evaluated after implementation to determine whether the stated objectives can be achieved. In practice, evaluation is naturally ubiquitous. Students are tested to identify problem areas. The teacher receives an interim report on its effectiveness in teaching. The curriculum can be investigated during development to ensure it fits the specific grade levels of skills and content for which it is designed to be taught.

Scriven (1967) distinguishes between summative and formative evaluation. When studying curriculum evaluation. Both types can help. Summative evaluation serves to assess all programs, including all the values of the program elements in the total school curriculum.

Meanwhile, formative evaluation includes making judgments and trying to distinguish specific cases. Information obtained from formative evaluations contributes to program revisions or improvements. Curriculum developers can change and improve the curriculum before it is completed.

Cronbach (1982) sees curriculum evaluation as a component of the decisionmaking process: "we define evaluation as part of collecting and using information to make decisions about educational programs". (Lewy, 1977) proposes to be more specific and views formative evaluation in the curriculum process. He views that "The essence of evaluation is the provision of information for the benefit of decision-making in every stage of curriculum development. This information pertains to the program as a complement or only as part of a component. Evaluation also includes criteria selection, data collection, and data analysis".

\section{Problems and alternative solutions from the developed Islamic-based Civics curriculum at SMP Negeri Gugus 05, Bandung Regency}

a) The problem with the Islamic-based Civics curriculum at SMP Negeri Gugus 05, Bandung Regency which was developed

The application of the Civics curriculum based on the developed Islamic values cannot be separated from problems, and of course, there must be a solution to overcome them. 


\section{SMPN 1 Cileunyi}

1) The problems of implementing the Islamic values-based Civics curriculum that was developed

- SMPN 1 Cileunyi, the implementation of the 2013 curriculum is still in the transition period from the 2006 curriculum to the 2013 curriculum. So schools have not found the suitable learning model to implement the 2013 curriculum in the learning process.

- In the Regulation of the Minister of Education and Culture no. 68 of 2013 concerning the basic framework and structure of the Junior High School/Madrasah Tsanawiyah curriculum, it is stated that the time allocation for Civics is 3 hours of lessons in one week. In its implementation at SMP Negeri 1 Cileunyi there are still 2 hours of lessons in one week.

- One of the peculiarities of the education pattern at SMP Negeri 1 Cileunyi is integrative. It is hoped that this pattern will integrate faith, science, and charity between theory and practice in one unit. However, in practice, there are no documents in the form of lesson plans or syllabus that show the implementation of the developed curriculum.

2) Alternative Solution

- The school cooperates with teachers in developing a Civics curriculum based on Islamic values. One of the ways carried out by SMP Negeri 1 Cileunyi is the School-Based Lesson Study (LSBS) activity which is carried out routinely every Friday in one semester there are 6 meetings for all subjects. The steps of LSBS are making lesson plans, determining the method to be used, predicting the things that will be faced. In the implementation of LSBS, there will be a selection of model teachers, class selection and lesson plans that will be used. Before the teacher does it in class, the teacher does it in front of other teachers. The results of the peer teaching will produce input and criticism which are expected to be corrected before the model teacher practices it in front of the students or other terms is an open class.

- To apply time allocation to Islamic values-based Civics learning developed by the Minister of Education and Culture Regulation, the principal and deputy principal worked together to establish a policy of increasing the time of lesson hours from two hours per week to three hours per week.

- One solution is for schools collaborating with foundations to hold training in making learning documentation by involving curriculum experts. So far, what has been done by SMP Negeri 1 Cileunyi is to consult with school supervisors in terms of procuring learning documents. However, the consultation results have not yet arrived at the procurement of learning documents.

\section{SMP Negeri 2 Cimenyan}

1) The application of developing a Civics curriculum based on Islamic values

- SMP Negeri 2 Cileunyi will start implementing the 2013 curriculum so that, in practice, it is still in the transition period from the 2006 curriculum to the 2013 curriculum. So schools have not found a suitable learning model to implement the 2013 curriculum in the learning process.

- In learning the Islamic values-based Civics curriculum developed, SMP Negeri 2 Cimenyan has implemented the Islamic values-based Civics Education curriculum. Moreover, for Civics learning based on Islamic values, class VII is taught by one teacher. However, in practice, there are no documents in the form of lesson plans 
or syllabus that show the implementation of the curriculum.

2) Alternative Solution

- Schools cooperate with teachers in implementing Civics based on Islamic values.

- One solution is for schools to collaborate with curriculum experts to develop a Civics curriculum based on progressive Islamic values.

\section{SMP Negeri 1 Cilengkrang}

1) The problem of implementing a Civics curriculum based on Islamic values is still constrained by the teacher's lack of understanding of Islamic values.

- SMPN 1 Cilengkrang has just started implementing the 2013 curriculum so that its implementation is still in the transition period from the 2006 curriculum to the 2013 curriculum. So schools have not found a suitable learning model to implement the 2013 curriculum in the learning process.

- In the Minister of Education and Culture Regulation No. 68 of 2013 concerning the basic framework and structure of the Junior High School/Madrasah Tsanawiyah curriculum, it is stated that the time allocation for Civics subjects is 2 hours of lessons in one week. In its implementation at SMP Negeri 1 Cilengkrang, additional hours of lessons are still needed to achieve learning objectives.

- In Civics learning, SMP Negeri 1 Cilengkrang has implemented a Civics curriculum based on Islamic values that were developed. However, in practice, there are no documents in the form of lesson plans or syllabus that show the implementation of the curriculum.

2) Alternative Solution

- The school cooperates with the teachers in making the syllabus and lesson plans for Islamic values-based Civics materials, which are developed and implemented so that formal learning is applied in schools.

- To apply time allocation to Islamic values-based Civics learning, which was developed by the regulation of the minister of education and culture, the principal and deputy principal worked together to establish a policy of increasing study hours from two hours per week to three hours per week.

- (C) One solution is for the school to work together with the school committee and teachers to conduct training in making learning documentation by involving curriculum experts.

An alternative to the developed Islamicbased Civics curriculum at SMP Negeri 1 Cileunyi, SMP Negeri 2 Cimenyan and SMP Negeri 1 Cilengkrang, SMP Negeri Gugus 05, Bandung Regency

Alternative Solutions for SMP Negeri 1 Cileunyi, SMP Negeri 2 Cimenyan and SMP Negeri 1 Cilengkrang:

1) Schools cooperate with teachers in implementing Civics based on Islamic values.

2) One solution is for schools to collaborate with curriculum experts to develop a Civics curriculum based on progressive Islamic values.

SMP Negeri 1 Cileunyi, SMP Negeri 2 Cimenyan and SMP Negeri 1 Cilengkrang

1) The problem of implementing a Civics curriculum based on Islamic values is still constrained by the teacher's lack of understanding of Islamic values.

- SMP Negeri 1 Cileunyi, SMP Negeri 2 Cimenyan and SMP Negeri 1 Cilengkrang have just started implementing the 2013 curriculum. In practice, it is still in the transition period from the 2006 curriculum to the 2013 curriculum. So schools have not found a suitable learning model to 
implement the 2013 curriculum in learning.

- In the Minister of Education and Culture Regulation No. 68 of 2013 concerning the basic framework and structure of the Junior High School/Madrasah Tsanawiyah curriculum, it is stated that the time allocation for Civics subjects is 2 hours of lessons in one week. In its implementation at SMP Negeri 1 Cileunyi, SMP Negeri 2 Cimenyan and SMP Negeri 1 Cilengkrang, additional hours of lessons are still needed to achieve learning objectives.

- In Civics learning, SMP Negeri 1 Cileunyi, SMP Negeri 2 Cimenyan and SMP Negeri 1 Cilengkrang have implemented a curriculum based on Islamic values that was developed. However, in practice there are no documents in the form of lesson plans or syllabus that show the implementation of the curriculum.

2) Alternative Solution

- The school cooperates with the teachers to make the syllabus and lesson plans for Islamic values-based Civics materials developed and implemented so that formal learning is applied in schools.

- To apply time allocation to Islamic values-based Civics learning, which was developed by the regulation of the minister of education and culture, the principal and deputy principal worked together to establish a policy of increasing study hours from two to three hours per week.

- (C) One solution is for the school to work together with the school committee and teachers to conduct learning documentation by involving curriculum experts.

\section{Conclusion}

This study indicates that the development of an Islamist-based Civics curriculum can improve students' morals, meaning, in this case, Islamic religious values, such as honesty, responsibility, discipline, respect for others, tasamuh, values of nationalism and patriotism. Besides that, it can form complete students who behave and think logically with full confidence (religious) as good citizens of the Republic of Indonesia. In detail, the objectives of Islamic-based Civics in Junior High Schools in Cluster 05 Bandung Regency are to develop the potential of Islamic-based students in all dimensions of citizenship, namely: (I) citizenship attitudes, including firmness, commitment, and civic responsibility (civic confidence, civic commitment and responsibility). Civic responsibility); (2) civic knowledge (Civic Knowledge); (3) civic skills, including civic competence and civic responsibility, are reflected.

The Education Unit Level Curriculum (KTSP) of SMP Negeri 1 Cileunyi, SMP Negeri 2 Cimenyan, and SMP Negeri 1 Cilengkrang, school stakeholders make Bandung Regency, the substance refers to the revised Thirteen Curriculum, which is described based on philosophical, psychological, sociological, science and technology policies Bandung District Office as well as different local content.

The objective condition of the PPKn curriculum at SMP Negeri 1 Cileunyi, SMP Negeri 2 Cimenyan, and SMP Negeri 1 Cilengkrang, Bandung Regency, which the author found to be part of the substance (content) of the revised Thirteen Curriculum, does not contain the spirit of Islamic values. Even so, teachers provide support for religious substances in the learning process. However, they are still lacking, so teachers are needed who have two competencies: subject-centred design (material) competence and Learning-centered design for Civics and Islamic Values.

The design of Islamic-based Civics curriculum development is made and designed to improve students' morals by incorporating elements of Islamic religious 
values, such as honesty, responsibility, discipline, respect for others, tasamuh, values of nationalism and patriotism. The inclusion of spiritual substance into the Subjectcentered design (material) and Learningcentered design of Civics to achieve the goals of Civics' goals, which is based on Islam. So that it is reflected and manifested in the actions of kharimah morals.

Implementation of the Islamic-based Civics curriculum starts with preliminary activities, including student conditioning, communication of learning objectives, motivation, explaining the mechanism for implementing the learning experience and Islamic learning steps. The next step is the core activity, which includes learning activities, identifying problems. The teacher provides opportunities for students to ask questions about the material to be taught and the Islamic religious values contained in the PPKn material (characterized PPKn). The learning activity ended with a reflection activity, concluding the discussion results regarding the material and religious values contained in the Civics Education material and answering the questions posed by the students. Evaluation is done through written, oral and portfolio tests. The three tests can describe the internalization of Islamic values in the Civics Education material. Subjectcentred design (material) and Learningcentered design can be seen from the reflection of students' morals.

Problematic: The problem with Islamicbased Civics Curriculum Development in Junior High Schools is that the development of the Civics Education curriculum in internalizing attitude values, in reality, has a different character from the development of the Civics Education curriculum in cognitive and psychomotor aspects. People often want Islamic ones to do what they feel and think is good, but what they do is often different. Sometimes effective does not teach in intellectual ways. This shows that the problem of acting is a world separated from the world that exists within a person. This is indeed the case because in the real world, the determining variables are numerous and often beyond the ability and control of students. The solution: In developing an Islamic-based curriculum, it is necessary to foster/educate/teach an Islamic effective, requiring particular approaches and strategies and methods rather than developing an Islamic cognitive and psychomotor domain curriculum.

\section{References}

Ahmadi, Iif Khoiru, Amri, Sofan, \& Elisah, Tatik. (2011). Strategi pembelajaran sekolah terpadu. Jakarta: Prestasi Pustaka. Google Scholar

Alim, Muhammad. (2006). Perananan pendidikan agama dalam pembangunan moral. pendidikan agama islam upaya pembentukan pemikiran dan kepribadian muslim. Bandung. Google Scholar

Ancok, Djamaludin, Suroso, Fuad Nashori, \& Ardani, Muh Sungaidi. (2000). Psikologi islami: Solusi islam atas problemproblem psikologi. Pustaka Pelajar. Google Scholar

Arifin, Z. (2017, March 8). Wawancara Pengawas Pembina. (T. Prayitno, Interviewer)

Bukhari, M. I. (2014, May 16). Retrieved December 20, 2021, from https://muslim.or.id/21418-innamalamalu-binniyat.html

Cronbach. (1982). New Directions for Evaluasi. Dordrecht: Springer.

Juhana. (2016, August 11). Wawancara dengan Kepala Dinas Kab.Bandung. ( $T$. Prayitno, Interviewer)

Lewy, Arieh. (1977). Handbook of Curriculum Evaluation. Google Scholar

Nusa, P. (2011). Research Development Peneitiqn dan pengembangan: suntu Pengantar. Jakarta: Rajagrafindo Persada. 
Oemar, H. (2013). Pengembangan Kurikulm. Bandung: PT Remaja Rosdakarya.

Prayitno, T. (2017, May 22). Observasi Bersama Wawan Setiawan (Ketua Gugus 05). (W. Setiawan, Interviewer).

Rizal, S., S. (2021). Curriculum development: Islamic education philosophy perspective. Educational Reviewer:International Journal, 18(2). Google Scholar

Scriven, E. Johnson, M. (1967). Class size and achievement gains in seventh-and eighth-grade English and mathematics. Google Scholar

Sugiyono, Dr. (2013). Metode penelitian pendidikan pendekatan kuantitatif, kualitatif dan R\&D. Google Scholar

Sukmadinata. S. (2019). Pengembangan Kurikulum. Bandung: Remaja Rosdakary. Google Scholar
Tafsir, Ahmad, Supardi, Ahmad, Basri, Hasan, Mahmud, Mahmud, Kurahman, Opik Taupik, Fathurrahman, Pupuh, Priatna, Tedi, Supriatna, Supriatna, Ruswandi, Uus, \& Suryana, Yaya. (2004). Cakrawala pemikiran pendidikan Islam (Vol. 1). Mimbar Pustaka: Media Tranformasi Pengetahuan. Google Scholar

Wahab, Abdul Azis. (2007). Teori dan Landasan Pendidikan Kewarganegaraan. Bandung: Alfabeta.

Wirataputra, U. S. (2001). Membangun' Etho's Demokrasi Melalui Proyek Belajar Kewargaranegaraan...Kami Bangsa Indonesia. Google Scholar

Yusran, Muhammad. (2017). Pemikiran Pendidikan Islam KH Muhammad Zaini Abdul Ghani. Google Scholar

Teguh Prayitno, Agus Salim Mansyur, Adang Hambali, Yuyun Nurul'aen (2022)

First publication right :

Journal of Social Science

This article is licensed under:

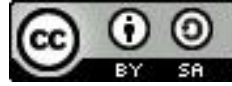

